\title{
Compromise report issued by White House AIDS commission
}

Washington

THE White House last week released without comment the final report of the Presidential Commission on the HIV [human immunodeficiency virus] Epidemic. The final report recommends a different approach from a draft report released last month (see Nature 333, 485; 1988) on the question of how the US federal government should establish effective leadership to counter the AIDS epidemic.

As expected, most commissioners disagreed with the last chapter of the draft report - written by commission chairman James D. Watkins - which recommended declaring the epidemic a national health emergency and setting up Surgeon General C. Everett Koop as an 'AIDS czar' to coordinate the national response.

Instead, the final report contains a compromise recommendation to the president to appoint a continuing sevenmember committee to oversee federal efforts against AIDS, and to establish an independent Department of Health. The report also urges the federal government to streamline procedures for responding to public health crises.

After insisting that it wanted its own evaluation of the AIDS crisis before acting, the Reagan White House does not appear likely to move quickly to implement any of the report's recommendations. Most of the suggested actions will not be paid for in the 1989 budget, and legislation to establish most of the policy changes called for in the report has yet to be introduced. With only six months left in office, the Reagan administration will be able to leave many of the tough decisions about AIDS to the next occupant of the White House.

\section{New faces for scientific publishing empire}

\section{Washington}

THE Institute for Scientific Information (ISI), once totally controlled by president and chief executive officer Eugene Garfield, has formed a partnership with JPT Holdings, a group of publishing entrepreneurs. Although it is not a sale, Paul Neuthaler of JPT Holdings describes his company's financial interest in ISI as "substantial".

Garfield has built the ISI publishing operation on the success of Current Contents, the popular weekly listing of contents of scientific publications. In recent years, Garfield has become involved in other ventures that have not been as financially rewarding - ISI Press, the Atlas of Science and the bi-weekly science newspaper, The Scientist. Opening a new office in Ireland also put a strain on ISI.

\section{Animal guidelines}

\section{London}

THE continuing need for cancer researchers to study the behaviour of tumours in live animals has prompted the publication of guidelines* on the welfare of such animals in laboratories. The guidelines are sponsored by the United Kingdom Coordinating Committee on Cancer Research (UKCCCR), and the emphasis is on informed judgement of humane endpoints. The authors are at pains to point out that their suggestions should not be taken as gospel, but can and should be modified in the light of new information and developing research needs.

Henry Gee

* UKCCCR guidelines for the welfare of animals in experimental neoplasia. Available from the UKCCCR secretariat, Medical Research Council, 20 Park Crescent, London W1N 4AL.
Under the new arrangement, Neuthaler and Joseph Palazzolo will join ISI as executive vice presidents. Garfield will remain as president and chief executive officer. JPT Holdings is headed by Theodore Cross, a veteran of the financial publishing world. He now owns Frost and Sullivan, a market research company and Faulkner \& Gray, Inc., publisher of newsletters in law, accounting and banking. Neuthaler says there are no immediate plans to alter ISI's operations, but in the long run the new partners may use their experience to move ISI into new areas such as newsletters and journals.

One problem for the new partners is what to do with The Scientist. Described by Garfield as a newspaper "covering the entire spectrum of the business and profession of science", the newspaper has had its share of troubles. Eighteen months after it began publication in October 1986 , the editorial offices were moved from Washington to Philadelphia. At the same time, there were major changes in the editorial staff, including Ellis Rubinstein replacing Tabitha Powledge as editor.

As a new publication, The Scientist was not expected to start making money for four or five years, and according to those involved with the newspaper it has been losing money as expected. The new partners have approached Verlagsgruppe Georg von Holtzbrinck of Stuttgart, West Germany, owners of Scientific American, to discuss the future of The Scientist. Other options said to be being considered are to maintain The Scientist within ISI, but market it more aggressively, or to cease publication altogether.

\section{Another win for UK academics on reform bill \\ London}

BRITISH academics have won another major victory in their campaign to ward off perceived threats to the independence and autonomy of universities posed by the government's Education Reform Bill, which completed its report stage in the House of Lords last week. Peers rejected plans to change the present grant system and replace it with tighter controls, which academics interpreted as signalling the introduction of contract funding.

In the original form of the bill, the new Universities Funding Council (UFC) was to award to universities "payments, subject to such terms and conditions as they see fit". But in an amendment, those words were replaced by "grants, specifying such particular obligations and subject to such general guidance as they see fit".

Lord Swann, who tabled the amendment, said the government wanted a system that was restrictive, bureaucratic and "hardly trusts anyone to do anything". The Association of University Teachers, which represents over 30,000 academics, said the amendment would temper the potentially wide-ranging powers of the UFC which threatened academic freedom. But the danger is not yet over: ministers may try to reverse the change when the bill goes to the House of Commons next week.

The government has already seen defeat at the hands of the academic lobby in the Lords when it was forced to accept inclusion in the bill of an amendment that gives statutory protection to academic freedom (Nature 333, 289; 1988).

Before facing another possible defeat, the government climbed down over its intention to make expensive university staff redundant and replace them with cheaper staff to do the same job. Instead, an academic may be made redundant only if the university abolishes the post.

Academics have welcomed the change. "This is wonderful news", said Professor Mark Richmond, chairman of the universities' Committee of Vice-Chancellors and Principals. "British universities would have been at a serious disadvantage in recruiting academic staff in the world market if this clause had not been altered."

As peers fought for academic freedom, academics at a conference organized by the Council for Science and Society were united in support of freedom for academics to carry out non-commercial research. Professor Martin Rees of the Institute of Astronomy at the University of Cambridge was concerned that there would be a majority of industrialists on the new Universities Funding Council. Christine McGourty 